\title{
Productivity and water use of five pasture grasses in Canterbury
}

F.J.PARRY. B.A. MCKENZIE and R.J.LUCAS

Plant Science Department, P.OBox 84, Lincoln University, Canterbury

\begin{abstract}
An experiment was conducted on a fertile Wakanui silt loam in 1991/1992 examining yield and water use of five perennial pasture grass species, Grasslands Hakari mountain brome (Bromus sitchensis), Grasslands Wana cocksfoot (Dactylis glomerata), Grasslands Roa tall fescue (Festuca arundinacea), Grasslands Marsden perennial ryegrass (Lolium perenne $x$ Lolium hybridum), Grasslands Maru phalaris (Phalaris aquatica). From 8 November, 1991 until 31 March, 1992 the highest yields were from Hakari and Maru at 11370 and $10870 \mathrm{~kg} / \mathrm{ha}$. Marsden, Wana and Roa yielded 8960, 8750 and $8190 \mathrm{~kg} / \mathrm{ha}$ respectively. From late January until the end of March growth conditions were not limited by water stress or nutrients. Pre-irrigation yields, when rainfall limited growth were 3840,3570 , 2720, 2520 and $2290 \mathrm{~kg} / \mathrm{ha}$ for Hakari, Maru, Marsden, Wana and Roa respectively. Total water use was not significantly different between species and averaged $400 \mathrm{~mm}$. Water use efficiency (WUE) was significantly higher for Hakari and Maru at 30.1 and $27.9 \mathrm{~kg} \mathrm{DM} / \mathrm{ha} / \mathrm{mm}$ respectively. The other three species had WUE's less than $23 \mathrm{~kg}$ DM/ $\mathrm{ha} / \mathrm{mm}$ of water. Neutron probe measurements showed all species extracted soil water from a depth of at least $110 \mathrm{~cm}$.
\end{abstract}

Keywords Bromus sitchensis, Dactylis glomerata, Festuca arundinacea, Lolium perenne $x$ Lolium hybridum, Phalaris aquatica, root depth, water use, water use efficiency, yield

\section{Introduction}

Pastoral farming in New Zealand depends primarily on ryegrass white clover pastures. While this mixture has been successful in most areas of New Zealand, it has been most successful where rainfall is reliable and soil fertility high (Macfarlane 1990). The severe droughts in Canterbury inthelate 1980s, emphasised the limitations of perennial ryegrass in dry conditions. Depending on the presence or absence of endophyte (Fletcher et al. 1990) farmers had to contend with ryegrass staggers or lack of persistence because of Argentine stem weevil.
Additionally, of the common pasture grasses. perennial ryegrass is the most susceptible to grass grub damage (Chapman 1990). Many dryland farmers have therefore been searching for pasture grasses which are better adapted to their conditions and are free of the above problems. Promotion of alternative species was aided by Milne \& Fraser (1990) who established 1600 ha of dryland species in a Drought Pasture Demonstration Programme in North Otago and South Canterbury.

Considerable work by others on alternative grass species has also been described: Fraser (1982) on prairie grass and phalaris; Brock (1983) on tall fescue and Lancashire \& Brock (1983) on tall fescue, phalaris and cocksfoot. There has. however, beenlittle detailed work published on the actual water use efficiency of alternative pasture grasses and their mixtures. Such studies should lead to improved understanding of the performance of pasture species in drought prone environments. The aims of this experiment were therefore to determine yield, water use and water use efficiency of a range of alternative pasture grasses.

\section{Materials and methods}

Over the 1991-92 summer growing season, growth and water use of Grasslands Hakari mountain brome (Bromus sitchemis). Grasslands Roa tall fescue (Festuca arundinacea), Grasslands Marsden hybrid ryegrass (Lolium perenne $\boldsymbol{x}$ Loliwn hybridum), Grasslands Maru phalaris (Phalaris aquatica) and Grasslands Wana cocksfoot (Dactylis glomerata) were studied. The $6 \times 1.66 \mathrm{~m}$ plots were sown on 6 and 7 of March 1991 in a fertile Wakanui silt loam soil. No clover was sown and herbicides were used to eliminate dicotyledon species. On 14 October $1991.50 \mathrm{~kg}$ nitrogen/ha was applied as calcium ammonium nitrate. After an establishment period of 5 months, pasture production was measured by reel mower cuts taken every month from July.

Soil water contents were measured from November 1991 to March 1992 using a neutron moisture probe (Troxler model 3333). One access tube was placed in each of the fourreplicateplotsofthe 5 treatments. Tubes $80 \mathrm{~cm}$ deep were placed in most plots but tubes $110 \mathrm{~cm}$ decp were placed in selected treatments in two replicates. Probe readings were taken every $10 \mathrm{~cm}$ and were transformed into volumetric water content (VWC) per 
$10 \mathrm{~cm}$ slice using the following calibration equation:

$$
\text { VWC }=-0.0119+0.727 \times \text { count ratio }
$$

Soil water content in the top $20 \mathrm{~cm}$ was determined by Time-Domain Reflectometry. Total soil water content was calculated by adding the water content of each slice in the profile. Water use (ET) was calculated for each period between measurements as follows (assuming no drainage):

$$
\mathrm{ET}(\mathrm{mm})=@ \mathrm{SWC}+(\mathbb{I}+\mathrm{R})
$$

where @ SWC = the change in soil water content from time 1 to time $2, \mathrm{I}=$ irrigation, $\mathrm{R}=$ rainfall.

The water use substudy started on 8 November 1991 and measurements were made every 2 weeks until 24 January. Plots were harvested on 16 December 1991, 16 January 1992, and 1 February 1992. Nitrophoska blue and ammonium sulphate $(63 \mathrm{~kg} \mathrm{~N} / \mathbf{h a}, 40 \mathrm{~kg}$ P/ha, $112 \mathrm{~kg}$ K/ha and43 kg S/ha) were applied on 17 January, 1992. Irrigation (165mm) was applicdtotheexperimentalarea from 24 to 31 January. This was followed by a period of 19 intensive soil water measurements conducted from 2 February to 31 March.

Results from the three pm-irrigation harvests have been combined to simplify results. Results were analyscd with analysis of variance and where there were significant differences lsd $(\mathrm{P}=0.05)$ were calculated.

\section{Results}

The weather data for the period of the study shows that mean daily temperatures were lower in November and December than long term means, but higher in January, February and March. However, mean daily miniium temperatures were from $2.9^{\circ} \mathrm{C}$ to $0.4{ }^{\circ} \mathbf{C}$ below long tenn means (Table 1). Rainfall was above average in November and December, but in January, February and March rainfall was only $43 \%$ of the long term mean

Table 1 Weather datu for Lincoln from November, 1991 until Much,

\begin{tabular}{|c|c|c|c|c|}
\hline \multicolumn{3}{|c|}{ November December January } & \multicolumn{2}{|c|}{ February March } \\
\hline $\begin{array}{l}\text { Mean daly } 15.8 \\
\max .\left({ }^{\circ} \mathrm{C}\right)(18.8)\end{array}$ & $\begin{array}{r}18.3 \\
(20.4)\end{array}$ & $\begin{array}{l}22.1 \\
(21.3)\end{array}$ & $\begin{array}{l}21.6 \\
(20.9)\end{array}$ & $\begin{array}{r}19.8 \\
(19.2)\end{array}$ \\
\hline $\begin{array}{l}\text { Mean daily } 6.2 \\
\text { min. }\left({ }^{\circ} \mathrm{C}\right)(8.1)\end{array}$ & $\begin{array}{c}8.3 \\
(10.4)\end{array}$ & $\begin{array}{c}11.1 \\
(11.5)\end{array}$ & $\begin{array}{c}9.3 \\
(11.4)\end{array}$ & $\begin{array}{l}7.0 \\
(9.9)\end{array}$ \\
\hline $\begin{array}{ll}\text { Rainfall } & 71.3 \\
\text { (mm/month) } & (57)\end{array}$ & $\begin{array}{l}80.0 \\
(57)\end{array}$ & $\begin{array}{l}28.0 \\
(60)\end{array}$ & $\begin{array}{l}35.3 \\
(54)\end{array}$ & $\begin{array}{l}10.2 \\
(57)\end{array}$ \\
\hline
\end{tabular}
1992. Long term means in parentheses
Dry matter yield and water use

Hakari and Maru produced significantly higher total yields than Roa, Wana and Marsden ( $\mathbf{P}<0.05$, Table 2 ). There were no significant differences in water use (ET) during the substudy period with all species using an average of $2.7 \mathrm{~mm} /$ day.

Table 2. Total dry matter yield ( $\mathrm{kg}$ DMha) of Rve pasture species, 8/1 1/91-1/2/92 (pre-irrigation), 2/2-31/3/92 (post irrigation).

\begin{tabular}{lccc}
\hline Cuttvars & Pre & Post & \multicolumn{1}{l}{ Total } \\
\hline Hakarl & 3840 & 7530 & 11370 \\
Roa & 2290 & 5890 & 8190 \\
Marsden & 2720 & 6230 & 8960 \\
Maru & 3570 & 7300 & 10870 \\
Wana & 2520 & 6230 & 8750 \\
SEM & 517 & 958 & 1313 \\
CV \% & 17 & 14 & 14 \\
P>F & 0.01 & 0.12 & 0.02 \\
\hline
\end{tabular}

\section{Water use efficiency}

Water use efficiencies (WUE calculated as $\mathrm{kg}$ DM/hal $\mathrm{mm}$ of ET) were significantly different for both the preirrigation and total periods at $\mathbf{P}<0.07$ (Table 3). Preirrigation water use efficiency was low at $13.6 \mathrm{~kg} \mathrm{DM} /$ $\mathrm{ha} / \mathrm{mm}$. During the intensive measurement period after

Table 3 Water use efficiency (kg DM/ha/mm ET) of five pasture speciea, 8/11/91-1/2/92 (pre-irrigation), 2/2-31/3/92 (post irrigation) and total for the season.

\begin{tabular}{lccc}
\hline Cuituars & Pre & Post & Total \\
\hline Hakari & 17.1 & 47.8 & 30.1 \\
Roa & 11.3 & 38.1 & 21.9 \\
Marsden & 11.1 & 40.7 & 22.3 \\
Maru & 16.8 & 47.1 & 27.9 \\
Wana & 11.8 & 37.7 & 22.9 \\
SEM & 2.85 & 6.10 & 3.49 \\
CV\% & 21 & 14 & 14 \\
P>F & 0.06 & 0.09 & 0.07 \\
\hline
\end{tabular}


irrigation overall mean WUE was $42 \mathrm{~kg} \mathrm{DM} / \mathrm{ha} / \mathrm{mm}$. An unprotected LSD test indicated that. Hakari had a total WUE that was 24.26 and $27 \%$ greater than that of Wana, Marsden and Roa respectively. The overall total WUE was $25 \mathrm{~kg} \mathrm{DM} / \mathrm{ha} / \mathrm{mm}$.

\section{Water extraction patterns}

All species extracted water from $80 \mathrm{~cm}$. Several treatments were measured to a deeper level in the latter part of the intensive measurement period. Extraction occurred to depths of at least $110 \mathrm{~cm}$ in these treatments as illustrated by Maru (Figure 1). In all treatments, extraction was relatively even throughout the soil profile.

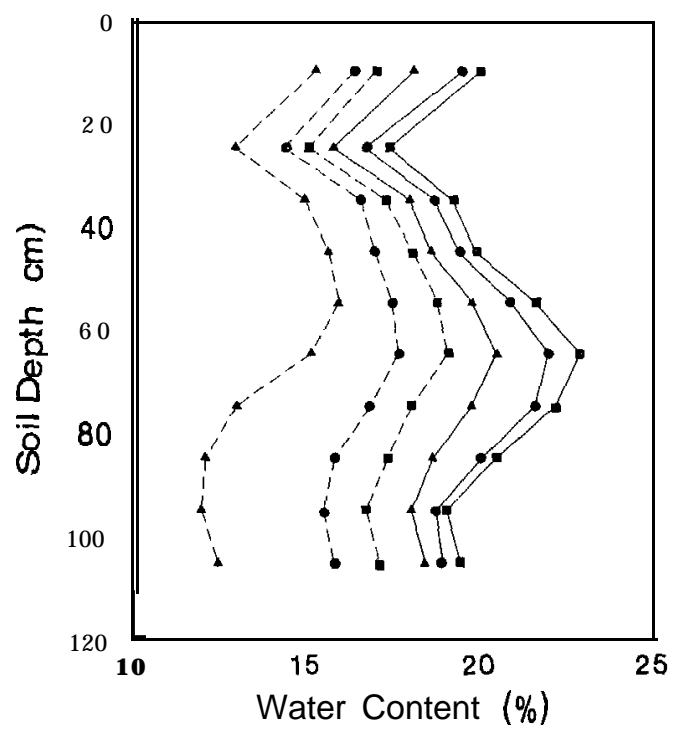

Figure 1 Changes in volumetric sail water content of Grasslands Man phalaris during the intensive water measuring period in February and March 1992 Days after end of irrigation (1/2/1992): 29 (a); 32 (e); 36 (A); 39 (D); 43 (0); 58 (A). Final three dates with dashed line. Data are the means of four replicates down to $80 \mathrm{~cm}$ and of two replicates at greater depths.

\section{Discussion}

Overall, the production rates of approximately $57-79 \mathrm{~kg}$ $\mathrm{DM} / \mathrm{ha} / \mathrm{d}$ were high, relecting the good growing conditions and infrequent defoliation. The 60 day period after irrigation, under ideal growing comnditions gave production rates of $98-125 \mathrm{~kg} \mathrm{DM} / \mathrm{ha} /$ day. Roa and Wana which produced least are known for their slow establishment (Langer 1990). Marsden and Roa plots became infested with leaf rust during the intensive measuring period, this probably suppressed production. Maru, also known as a slow establisher, had high yields in this experiment. Maru becomes semi-dormant when mois- ture stressed. The high production indicates Maru certainly did not reach this state before irrigation.

The lack of significant differences in total water use betweenthe grasses was expectedunderno stress conditions. Only under drought conditions would any differences in rooting depth. leaf area index or stomatal conductance play an important role in soil moisture availability. Hence, the experiment is continuing and further measurements will be taken when the plots are experiencing severe water stress.

Water use efficiencies must be treated with caution as significant water was extracted from levels below 80 $\mathrm{cm}$. This must have resulted in an overestimation of water use efficiency. Indeed the water use efficiencies reported during the intensive period of measurement (42 $\mathrm{kg}$ DM/ha/mm water) were much higher than those reported for moderately stressed swards of lucerne/ Matua prairie grass, lucerne/Maru phalaris and luceme at 20,22 . and $25 \mathrm{~kg} \mathrm{DM} / \mathrm{ha} / \mathrm{mm}$ water respectively (McKenzie et al. 1990).

The extraction of water below $80 \mathrm{~cm}$ was surprising for pasture grasses which are generally considered shallow rooted. Hayman \& Stocker (1982) found ryegrass/ white clover pasture could extract water down to $90 \mathrm{~cm}$. On a similar soil type at Lincoln University, McKenzie et al. 1990 found that Maru phalaris, Matua prairie grass and Nui ryegrass had roots down to at least 70.60 and 40 $\mathrm{cm}$ respectively. The deeper extraction in this study was also surprising for young swards some of which may not have been fully established. Further experimentation will be carried out in spring of 1992 to assess the maximum water extraction depths.

\section{Conclusions}

1. Some species, e.g. Grasslands Hakari mountain brome and Grasslands Maru phalaris are higher yielding and have, higher WUE than perennial ryegrass under good summer growing conditions.

2. Under good growing conditions grasses extract water from at least $110 \mathrm{~cm}$.

3. Further work is required to determine: absolute effective rooting depth and water extraction depths; mechanisms for superior warm season performance of some grass species; yield capabilities and water use efficiencies under severe water stress; and the effect of aggressive competition for water on grass/clover sociability.

\section{REFERENCES}

Brock, J.L. 1983. 'Grasslands Roa' tall fescue. A review. Proceedings of the NZ Grassland Association 44: 74-80. 
Chapman, R.B. 1990. Insect pests. In. Langer, R.H.M. (ed.). Pastures their ecology and management. Auckland: Oxford University Press.

Fletcher. L.R.; Hoglund, J.H.; Sutherland, B.L. 1990. The impact of Acremonium endophytes in New Zealand, past, present and future. Proceedings of the NZ Grassland Association 52: 227-235.

Fraser, T.J. 1982. Evaluation of Grasslands Matua' prairie grass and 'Grasslands Maru' phalaris with or without luceme in Canterbury. $N Z$ journal of experimental agriculture 10: 235-237.

Hayman, J.M.; Stocker, R.V. 1982. Soil water extraction patterns under pasture and luceme on two soil types in Canterbury. Proceedings of the Agronomy Society of NZ 12: 61-63.

Lancashire, J. A.; Brock, J.L. 1983. Management of new cultivars for dryland. Proceedings of the $\mathrm{NZ}$ Grassland Association 44: 61-73.

Langer, R.H.M. Pasture Plants. pp. 39-74. In. Langer, R.H.M. (ed.). Pastures their ecology and management. Auckland: Oxford University Press.

Macfarlane, A.W. 1990. Field experience with new pasture cultivars in Canterbury. Proceedings of the NZ Grassland Association 52: 139-143.

Milne. G.;Fraser, T. 1990. Establishment of 1600 hectares in dryland species around Oamaru/Timaru. Proceedings of the NZ Grassland Association 52: 133-138. 